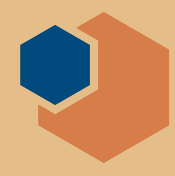

\title{
US administration makes efforts to increase inclusiveness in STEM industries
}

\author{
www.whitehouse.gov/demo-day
}

$\mathrm{S}$ cience, technology, engineering, and mathematics (STEM) fields have a well-recognized diversity issue. Orlando Auciello, 2013 president of the Materials Research Society (MRS) addressed diversity in materials in the August 2013 issue of the MRS Bulletin saying, "The scientific and engineering communities must strive to become more inclusive, engaging all geographic and demographic groups in advancing science and technology. The Materials Research Society recognizes that diversity drives innovation, excellence and new discoveries. Although progress has been made, segments of our worldwide scientific community still remain a largely untapped resource in research and innovation."

The US government has recognized this problem and is trying to create opportunities to increase diversity in STEM-based industries through inclusive entrepreneurship initiatives. Entrepreneurship has been an area of focus for the Obama administration since 2011 with the launch of Startup America, which addresses entrepreneurial hurdles such as access to capital, connecting with mentors, and barriers associated with moving innovative ideas from the laboratory to the market. Many of the more recent initiatives under this umbrella have a twofold focus: encouraging diversity and entrepreneurship.

Part of the administration's effort has been in selecting leaders, namely Jo Handelsman and Megan Smith, to join the White House Office of Science and Technology Policy (OSTP) and spearhead the inclusive entrepreneurship initiatives.

Confirmed by the US Senate in June 2014, Handelsman serves as the OSTP's

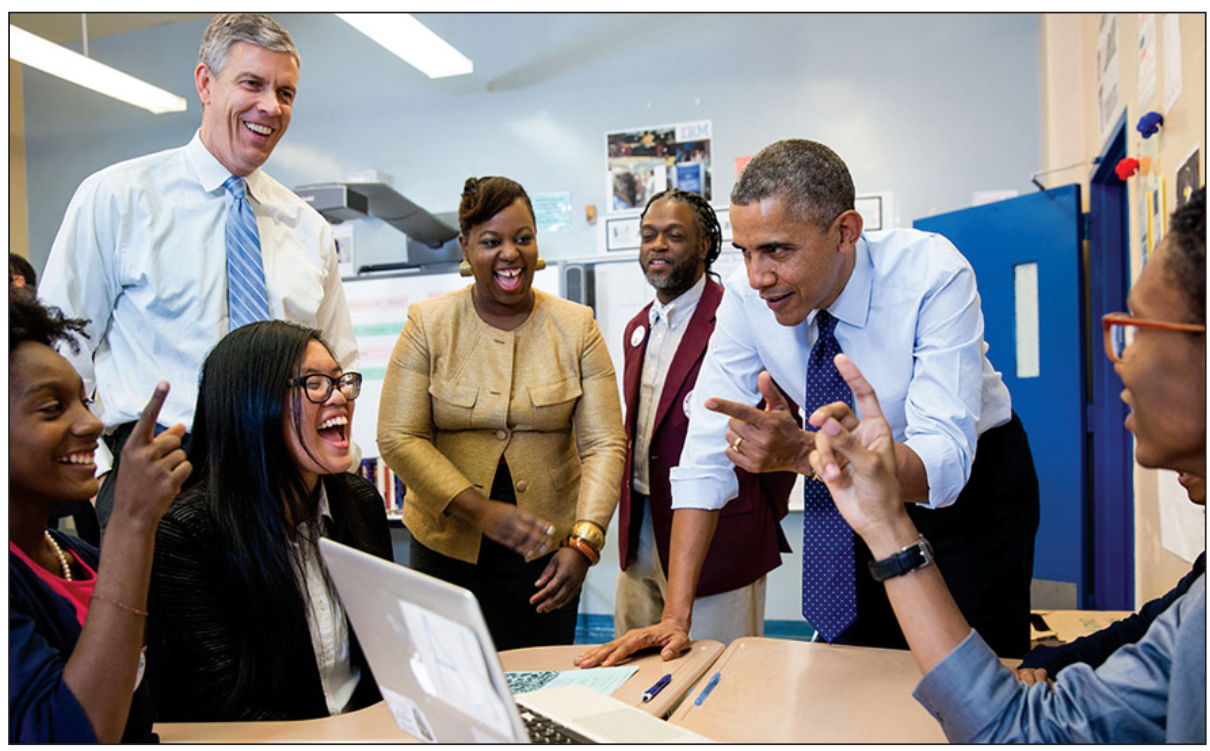

The inaugural White House Demo Day presented an inclusive event where 30 startup teams joined President Obama to demonstrate their business ideas and stories. Credit: White House.

Associate Director for Science. An academic who previously held positions at Yale University and the University of Wisconsin-Madison, Handelsman is an expert on science education and has been recognized for her research on women and minorities in science. While Handelsman believes that "education can drive [diversity in] other areas by making diverse graduates available to the workforce," she left her role in academia to join the administration because she recognizes that changing national policy can have a broader impact on STEM, education, and science. Handelsman describes diversification in STEM as "the right thing to do" and explained that "diverse groups are more creative and there is talent being wasted among people who are discouraged from STEM despite having tremendous potential to contribute."

Megan Smith was named the United States Chief Technology Officer (CTO) in September 2014. Smith is an engineer and technology evangelist whose career has spanned entrepreneurship to leadership in Fortune 500 companies. Diversity within technology-based fields has long been a focus for Smith, and she has led a number of efforts to increase diversity throughout her career. Most recently she served as a vice president at Google where she co-created SolveForX, a project to encourage collaboration between scientists, engineers, inventors, and artists from a diverse range of backgrounds to use science and technology to solve global issues, and started Women Techmakers, an initiative to support and empower women in technology. "We need to shatter the notion that women and people of color cannot be represented equally in STEM fieldsboth in the team and as tech founders," said Smith. 
Handelsman and Smith both acknowledge the difficulties associated with achieving greater inclusiveness in STEM. "Unconscious and institutional bias, harassment, and other discriminatory cultural behaviors pervade our startups, companies, venture partnerships, boardrooms, academic institutions, online conversations, communities, and classrooms," said Smith. In addition, Handelsman noted the lack of "role models and images of diverse people in STEM in mass media." Smith agreed saying, "we need to see a far more accurate media picture of innovation history with inclusive STEM representations telling the whole story and updated current media reflecting all of America-from our classroom materials to block-buster films." While fixing these bias issues won't be easy, according to Smith, "it's in our control to work together to eliminate them."

In addition to its staffing efforts, the administration hosted the first ever White House Demo Day on August 4, 2015. Over 30 startup teams joined President Obama at the White House to demonstrate their business ideas and stories. According to the Fact Sheet on the event, the White House Demo Day focused on inclusive entrepreneurship by drawing together a diverse group of founders from all across the United States "including those underrepresented in entrepreneurship like women and people of color."

Several of the businesses showcased at the White House Demo Day were either founded by materials scientists and/or utilize materials-based technologies. These companies span a wide range, from a startup that recycles critical metals from e-waste (such as trashed cell phones and computers), to a company developing the next generation of lowcost batteries, to a startup that developed and is commercializing an algae-derived gel that can quickly stop traumatic bleeding, to a company that has developed low-cost camera balls that can be thrown by soldiers and first responders to scout dangerous situations. The founders of the companies highlighted here, and of most of the startups that participated in the White House Demo Day, are minorities in STEM-based industries - women, people of color, or both. Highlighting and encouraging their leadership in these entrepreneurial companies is one way the administration is attempting to increase diversity in US industry.

President Obama also used the White House Demo Day to announce several administration efforts to help build a more inclusive and diverse pipeline for STEM-based industry. The first of two key efforts that were highlighted at the event was the announcement of 116 winners of the Growth Accelerator Fund and the president's "Startup in a Day" initiative. Both prizes are administered by the Small Business Administration (SBA) and are meant to promote entrepreneurship in communities across the country.

The second highlighted administration effort is a scale-up of the National Science Foundation's (NSF) I-Corp Program. I-Corp pairs NSF-funded scientists and engineers with business mentors as they complete a training program focused on entrepreneurship and movement of technologies from the laboratory into the marketplace. This program, started in 2011, has already produced some impressive results with over 500 teams completing the training, resulting in 260 companies that have together raised more than $\$ 40$ million in funding from nongovernment sources. The I-Corp Program expansion establishes or grows partnerships with other federal agencies including the US Departments of Agriculture, Defense, Energy, and Homeland Security as well as the National Institutes of Health, the National Security Agency, and the SBA.

The administration has also cultivated relationships with tech-industry leaders and has enlisted their help in promoting diversity in entrepreneurship. The White House Demo Day was used as an opportunity to announce a number of private sector commitments to help advance inclusiveness in industry. Among them are commitments from venture capital firms, engineering deans, and major technology companies to take action to advance diversity in the pipeline, provide new opportunities for underrepresented minorities (including women) in the entrepreneurial ecosystem, and ensure inclusive recruitment and hiring as well as consideration of more diverse candidates for senior executive positions in technology industries.

A number of technology companies that employ materials scientists and engineers were among the industry leaders that committed to advancing inclusiveness. Specific materials-relevant examples of the commitments announced at the White House Demo Day include mentorship and job placement assistance to bring more women back to the workplace at IBM; an investment of USD $\$ 5$ million by Intel to deepen its ongoing partnership with the Georgia Institute of Technology to diversify the engineering pipeline by attracting and retaining women and underrepresented minorities; and a commitment to increasing diversity in management positions by Xerox and Microsoft through the establishment of a requirement that women and minorities must be interviewed among the final pool of qualified candidates.

The commitments announced at the White House Demo Day build on existing strategies for some of these techleading companies. Intel has already invested USD\$125 million in their Intel Diversity Fund (for women and underrepresented entrepreneurs), and has committed to employing a workforce that represents American demographics by 2020. Microsoft already requires employees to complete unconscious-bias training and supports ongoing partnerships with the Technology Education and Literacy in Schools Program as well as the Network for Teaching Entrepreneurship — programs that seek to build a more diverse workforce. Getting more industry partners to support inclusivity is important because according to Handelsman, "industry can drive others by demanding diversity from universities and creating a competition among companies for the best talent."

Jennifer A. Nekuda Malik 